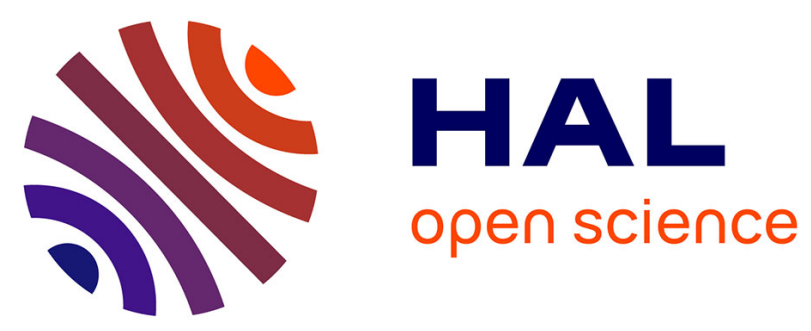

\title{
Priority education policies in Belgium: two modes of regulation of the effects of a market logic
}

\author{
Nathanaël Friant, Marc Demeuse, Angeline Aubert-Lotarski, Ides Nicaise
}

\section{To cite this version:}

Nathanaël Friant, Marc Demeuse, Angeline Aubert-Lotarski, Ides Nicaise. Priority education policies in Belgium: two modes of regulation of the effects of a market logic. Marc Demeuse, Daniel Frandji, David Greger, Jean-Yves Rochex. Educational Policies and Inequalities in Europe, Palgrave MacMillan, pp.344, 2012, 9780230302037. hal-00763942

\section{HAL Id: hal-00763942 \\ https://hal.science/hal-00763942}

Submitted on 11 Dec 2012

HAL is a multi-disciplinary open access archive for the deposit and dissemination of scientific research documents, whether they are published or not. The documents may come from teaching and research institutions in France or abroad, or from public or private research centers.
L'archive ouverte pluridisciplinaire HAL, est destinée au dépôt et à la diffusion de documents scientifiques de niveau recherche, publiés ou non, émanant des établissements d'enseignement et de recherche français ou étrangers, des laboratoires publics ou privés. 


\section{Priority Education Policies in Belgium: Two Modes of Regulation of the Effects of a Market Logic ${ }^{1}$}

Nathanaël Friant, Marc Demeuse, Angeline Aubert-Lotarski and Idesbald Nicaise

\section{Introduction}

An important feature of the Belgian context is the 'communautarisation' ' of education policies. Since 1989 teaching has fallen within the competence of the communities, whereas until then it came under the Federal state. It is the three language-based communities (the French-, Flemishand German-speaking communities) that manage similar but completely independent education systems, each covering part of the country ${ }^{3}$. In this chapter we will base our account on the French and Flemish communities. The first part deals with the general context of the education systems of these two communities and recounts their joint move towards equity up to 1989. The second part is centred on the priority education policies in the French Community. The targeted populations and the actions prescribed are analysed on the basis of official documents. Their effective implementation and the evaluation of their effects (whether desired or not) is then discussed on the basis of research and the scientific literature available. The third part of this chapter analyses, in the same way, the priority education policies in the Flemish Community. The chapter concludes, as a summary, by examining the similarities and divergences which exist between the two communities.

In Belgium, schooling is compulsory and free for a period of 12 years, which begins in the school year in which the child reaches the age of 6 and ends when the pupil reaches the age of $18 .^{4}$ Pre-school (optional, and for a duration of three years) and primary education (between ages $6 \frac{1}{2}$ and 12) are grouped together under the term 'fundamental education'. Secondary education, lasting six years, is made up of three 'degrees', each lasting two years. The first degree in theory provides a common structure for all pupils (Demeuse \& Lafontaine, 2005). Regarding the second cycle, secondary education is divided into $\operatorname{courses}^{5}$ with different objectives and opportunities, but also with a marked social and academic recruitment (Demeuse, Lafontaine \& Straeten, 2005; Demeuse et al., 2007). At the base of the education system is the freedom of education, written into Article 24 of the Belgian Constitution. This freedom applies to two aspects: (1) freedom, for pupils and their family provided by the law dated 29 May 1959, to choose the educational institution that they want; ${ }^{6}$ and (2) freedom to organise schools. There are a number of consequences to this freedom of education, and it will be seen that they are related to the priority education policies followed in Belgium. The first consequence is the organisation of the education system into various networks, ${ }^{7}$ each with its own educational project, and in which schools and teachers enjoy freedom as to how teaching is carried out. All the various organising authorities are given public finance established on an equal footing, except for the school infrastructures. Community decrees define the missions of fundamental and secondary education, the objectives of each type of teaching and the core competencies ${ }^{8}$ which all pupils must be attain, while leaving a free choice of the teaching methods to be used. Consequently, pupil evaluation depends on the school and the teacher. At the present time in Belgium there are no certifying external evaluations providing a comparable measurement of pupils' attainments at any level, thus making comparison among schools impossible, except in the French Community at the end of primary education. ${ }^{9}$ 
The freedom of teaching also results in a per capita funding system for each school. This has led to an education system qualified as 'quasi-market' (Vandenberghe, 1996). This concept reflects the situation of an education system characterised by the simultaneous presence of public funding, a free choice of school and a way of calculating the budget of each school according to the number of pupils registered (Delvaux, Demeuse \& Dupriez, 2005). There consequently exists an issue surrounding the way pupils are distributed around the schools, which structures competitive, asymmetrical and territorialised relations of interdependence (Maroy \& Delvaux, 2006). They are competitive, not only in relation to the number of pupils registered in the school (first-order competition), but also in regard to pupils' academic and socio-economic characteristics (second-order competition). They are asymmetrical because, on the basis of both the type of pupils they take in and the movement of these pupils between schools, schools can be ranked, some receiving mainly pupils that the others do not want. Finally, these interdependences are territorialised: geographically close schools are interdependent, whatever their network or their offer. While these competitive interdependences structure the way schools act, they also contribute to producing significant inequalities by establishing a cleavage between selective schools and 'ghetto' schools. ${ }^{10}$

A number of studies (Vandenberghe, 2000; Dupriez \& Vandenberghe, 2004; Dupriez \& Dumay, 2006) have shown that the educational quasi-markets in Belgium lead, by the segregations that they imply, to significant inequalities in school results. The two surveys of 2000 and 2003 by the Organisation for Economic Co-operation and Development Programme for International Student Assessment (OECD PISA) showed a major difference in scores, ranging between the 25 per cent of 15-year-old pupils whose socio-economic index was the highest and the 25 per cent of pupils whose socio-economic index was the lowest. They also underlined the role that secondary schools play in the measured differences in pupils' attainments, these differences themselves being mainly explained by the average socio-economic level of the schools (Baye et al., 2004). This segregation effect is illustrated in Figure 3.1, where the variance of the results in the 2003 PISA mathematics survey is analysed on a country-by-country basis.

The total variances were standardised in relation to the OECD average. A figure higher than 100 means than the variance is higher than the average of the participating countries and, conversely, if the figure is lower than 100. Figure 3.1 illustrates firstly the fact that the total inequality (reflected by the rate of variation) between 15-year-olds is higher in Belgium than in all the other countries studied. 


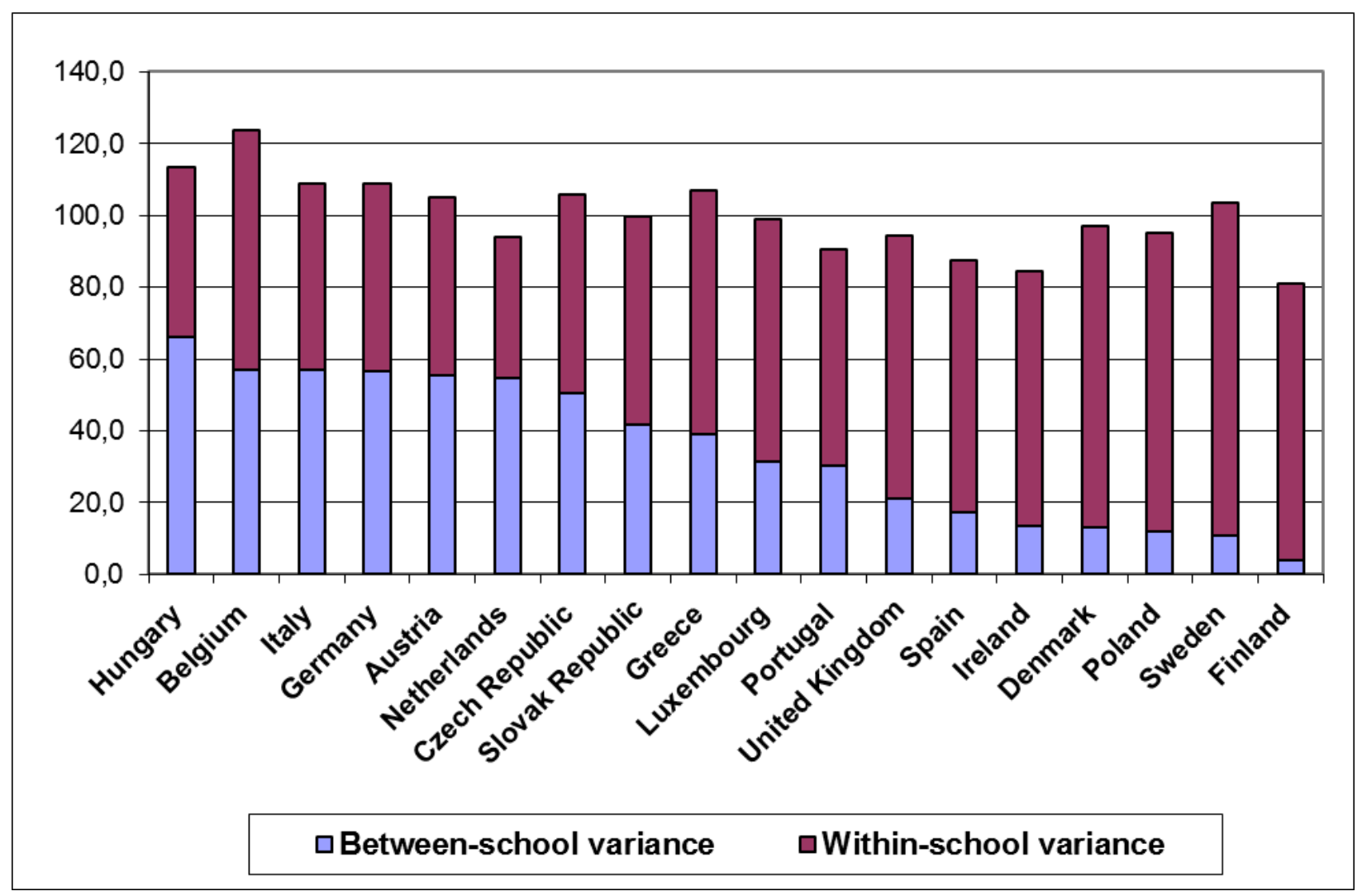

Figure 3.1 - Performances in mathematics by 15-year-olds, reflected in the 2003 PISA survey: variances between and within schools.

Figure 3.1 also illustrates the breakdown, by means of a multilevel analysis, of the total variance in results according to school or individual. The lower (darker) section of each bar represents the variance between schools (the amount variation that can be allotted to the differences between schools), while the upper (lighter) section reflects the variance between pupils within a school. Once gain, Belgium finds itself in an unenviable position, because no country except Hungary does worse in terms of inequalities between schools. In other words, this graph shows the enormous impact of the competition generated by the quasi-market system: the Belgian education systems are characterised by large inequalities between schools - whether because of the composition of their pupil population (social and academic segregation) or because of other factors. The causal relationship between competition and social and academic segregation in education was analysed in depth by V. Vandenberghe (1996) and was illustrated for several countries by A. Björklund et al. (2006), S. Bradley \& J. Taylor (2000) and N. Hirtt (2002).

This, then, is the educational landscape, marked by strong social inequalities, reinforced by the structures and the rules of funding, which forms the backdrop against which priority education policies aim to make corrections. They are, in fact, the current result of a 'move towards equity' in education (Demeuse, 2005). From 1830 until the present, the progressive appearance and coexistence of a certain number of moves towards greater equity can indeed be identified, at different times according to the levels of education. A certain amount of regularity 
can be perceived in the progression of these moves forward. Whether they relate to fundamental education initially, then to secondary or finally higher education, they progress in three stages:

- $\quad$ quantitative democratisation: this involves opening up access to education for all;

- qualitative democratisation: this involves equalising access to the noblest courses of study, in particular by systems of individual assistance based on merit;

- $\quad$ setting up priority education policies to ensure equality of results.

These three stages correspond to various models of justice shared at a given time for a given level of education. In this sense, the move towards greater equity in the Belgian education system can be traced by referring to the four conceptions of equity presented by A. Grisay (1984) and by Demeuse, Crahay \& Monseur (2001, 2005): equal access to an equality of social realisation, via the stages of equality of treatment and equality of results. These various stages may coexist at a given time because the democratisation of the various levels does not take place at the same time. Moreover, the changes that determine the move from one stage to another act gradually.

\section{Priority education policies in the French Community of Belgium}

The parallel pursuit of a move towards equity

As of 1989, the French Community and the Flemish Community have been continuing separately, but in parallel, their move towards equity, in particular by implementing priority education policies. These policies are underpinned by two fairly similar conceptions of equity: equality of attainments and equality of social realisation.

These conceptions of equity are characterised by the denunciation of all situations in which the unequal quality of teaching ${ }^{11}$ amplifies initial inequalities (Grisay, 1984). They preach equality of attainment for essential competencies, or equal possibilities of using the acquired competencies and social realisation. In this way they accept and encourage unequal treatment according to the principle of 'giving more to those who have less'.

This desire for equity features in the 'Missions' decree, promulgated in July 1997. It is particularly in evidence in the fourth objective pursued by teaching (decree dated 24 July 1997 , chapter III, Article 6):

- $\quad$ 'Promote the self-confidence and personal development of each pupil'.

- $\quad$ 'Help all pupils to appropriate knowledge and to acquire competencies for lifelong learning and to take an active part in economic, social and cultural life'.

- $\quad$ 'Prepare all pupils to be responsible citizens, able to contribute to the development of a united, democratic, pluralistic society open to other cultures'.

- $\quad$ 'Provide all pupils with equal opportunities for social emancipation'. 
While the principle of equality of attainment and social realisation is behind the priority education policies in the French Community of Belgium, the conception and implementation of these policies are subordinated to the context where strict formal equality is constitutionally guaranteed between citizens (Articles 10 and 11 of the Belgian Constitution) and between pupils (Article 24 of the Belgian Constitution). They are governed by certain conditions:

- $\quad$ accurate and objective identification of the beneficiaries;

- $\quad$ the definition of an action plan aiming at correcting initial objective disadvantages;

- $\quad$ limiting additional resources in order not to encroach on fundamental freedoms of others, and make these additional resources proportional to the damages suffered;

- $\quad$ limiting the range of action to the objectives set.

As can be seen, these policies go beyond the principle of just, formal equality in the field of education, inherited from democratic ideals developed during the 18th century. This approach refers to the current of thought about compensatory learning approaches, according to which it is better to treat those who seem to start out with poorer chances differently because they belong to categories whose results are generally lower, rather than to offer a single and identical service that is known would widen the inequality gap still further because of undifferentiated treatment. The thinking behind such compensatory action therefore aims at substituting, for pupils whose personal 'unchangeable' characteristics ${ }^{12}$ are said to be too unfavourable, more advantageous educational characteristics, in order to reach a level of attainment comparable with that of pupils who start off with more going for them (Demeuse \& Nicaise, 2005).

And yet, these principles run up against the notion of freedom of choice for pupils and their parents, which accentuates the difficulty of planning and organising a compensatory system that must be able to adapt to rapidly changing school populations and that struggles to keep pace with the acquisition of statistical information. Finally, they must not conflict with other principles, such as the protection of private life: the acquisition and the use of the necessary data must respect these basic rights and not pose more problems than they solve (Demeuse \& Nicaise, 2005).

It is in this context that priority education policies, mainly centred on the socio-economic background of pupils, were introduced in the French Community of Belgium. These policies, whether they were the priority education zones, inspired by the French ZEPs and founded in 1989, positive discrimination policies, which replaced the ZEPs in 1998, or the Encadrement différencié $^{13}$ (ED) policy, which will replace positive discrimination in 2009, use mechanisms that vary the allocation of resources to schools. They stand out from other contexts, where the expression 'positive discrimination' refers to the concept of priority granted to people belonging to underprivileged groups.

\section{Priority education zones}

In 1989 the priority education zones (ZEPs) were founded. Unlike the solution adopted in France, the selection of schools was centralised. It was based on education criteria (course of study, orientation, number of school years repeated, etc.) and socio-economic and cultural criteria (poorly educated parents, unemployment rate, poverty, etc.) that were identical for all 
schools. The ZEPs were marked out by the commission for selection, assistance and evaluation of the projects for promoting academic success, and did not correspond to an administrative breakdown but to provisional zones according to the value of the criteria at any given time. There was then no mechanical system for attributing additional resources: they were subject to prior registration of a project by the school. The philosophy behind the way ZEPs were set up was to implement a principle of positive discrimination by measures that would be specific (i.e. directed specifically towards the underprivileged public), preventive, pupil-centred (no segmentation according to the levels of learning, nor according to networks) and open to the environment (parents, community life, etc.) (Conseil de l'Éducation et de la Formation, 1994). The French-speaking Belgian ZEPs, unfortunately from the standpoint of fundamental teaching, gave way to political pressure in favour of the inclusion or otherwise of schools within the zones, and suffered from resources being spread too thinly between many schools (Demeuse, 2005). Also, the idea of zones was badly suited to the context of free choice of school. Certain very old schools educating privileged pupils were located in disadvantaged urban areas, which poses a problem in regard to the specific nature of the action and population targeting. No data are available for the French Community to provide a solid evaluation of the results of the ZEP policy, which was replaced in 1998 by positive discrimination, still in force today.

Outside the ZEPs, and before the decree dated 30 June 1998 founding the positive discrimination policy, a series of mechanisms for solidarity between schools was set up in order to rebalance the budgets. The decree dated 14 March 1995 relating to the promotion of a successful school in fundamental teaching identifies 'priority' schools according to objective criteria such as a high percentage of pupils repeating a year, a large number of foreign pupils and unfavourable socio-economic situations. Additional resources are provided to support these schools. In addition, there are also mechanisms for solidarity between schools in the same network, which involve taking away certain resources and redistributing them to the least privileged schools.

\section{Positive discrimination}

The 'Missions' decree established equality of social emancipation as one of the aims pursued by the education system in the French Community. For this purpose, a decree aiming at ensuring equal opportunities for social emancipation for all pupils, in particular by implementing positive discrimination, was voted in on 30 June 1998. It defined the term positive discrimination in the French-speaking Belgian context as a

distinction made for the benefit of ordinary, fundamental education and secondary schools, organised or subsidised by the French Community, on the basis of social, economic, cultural and educational criteria (decree dated 30 June 1998, Article $\left.3.1^{\circ}\right)$

The positive discrimination mechanism consists of a modulated allocation of resources to schools according to the socio-economic background of the pupils who are enrolled there. This allocation of additional resources to schools identified as providing education for an underprivileged population is performed mechanically, by ranking the qualifying schools according to an objective criterion, an average socio-economic index, and allocating additional means to the least privileged schools according to this criterion. In 2002, another decree 
completed and clarified the 1998 decree, while preserving similar ways of identifying the beneficiaries. The socio-economic index was again to be used as a basis for a mechanism for modulated allocation of additional resources (for operating only) in 2004, when differentiated funding for schools was implemented, following the refinancing of teaching.

In 2009, the ED decree will replace the existing 'positive discrimination' decree, by allocating additional resources to more schools. This decree also preserves a similar way of identifying the beneficiaries.

\section{Calculating a socio-economic index}

In order to implement the positive discrimination policy (and later, the ED policy), an objective socio-economic status indicator, based on the district ${ }^{14}$ from which the pupil comes, has been created and is updated at least every four years by a team from several universities (Demeuse $e t$ al., 1999; Demeuse \& Monseur, 1999). A comprehensive socio-economic index was initially allotted to each district of the Kingdom, on the basis of 12 , then 11 variables, ${ }^{15}$ taking into account both the requirements imposed by the decree dated 30 June $1998^{16}$ and the scientific literature that finds them reliable as indicators for academic and/or social success. Each pupil is allotted the socio-economic index of the district he/she lives in. This index is a normal distribution metric variable that varies between -3.5 and +3.5 . It is recalculated every three years on the basis of the latest statistical data available.

The average of the socio-economic indices of the pupils is taken at the level of the site. ${ }^{17}$ The schools are then ranked from the least to the most privileged. The most underprivileged schools, until they cumulatively total approximately $12 \%$ of the pupils, receive positive discrimination. In secondary education, priority positive discrimination schools receiving additional resources can also be distinguished. ${ }^{18}$ In addition, other schools and/or sites can be added, according to objective criteria, to the lists drawn up using the procedure described above (decree dated 27 March 2002). The modulated assignment of resources to schools within the framework of positive discrimination in the French Community is therefore a dichotomous mechanism, defining a border between positive discrimination schools - which involve approximately $12 \%$ of pupils and benefit from additional resources - and schools of ordinary status.

The ED decree will soften this dichotomy. Indeed, 25 per cent of the most underprivileged schools will receive additional resources and the mechanism will use five levels of disadvantage, with a proportional resource allocation to each level.

\section{Criticism of the method of identification}

M. Demeuse (2002) identifies the main arguments justifying such a method for calculating the socio-economic index from the district where the pupils live and for determining the schools that will benefit on the basis of their population rather than the zones where they are located. The fact that the socio-economic index is not created from data collected directly from the pupils in the schools is because this approach was rejected by the legislator for at least two reasons. The first is related to respecting the private life of the pupils and their parents: both the law ${ }^{19}$ restricting individual collection of information about the characteristics of the family environment, and educational staff, are particularly reticent about putting on record information about pupils' socio-economic background. The second is related to how such data are encoded: this is 
expensive and relatively unreliable. ${ }^{20}$ This solution was selected on the basis of the results of former scientific studies (Ross, 1983; Demeuse, 1996, 2002), which show that an indirect indicator of the socio-economic status 'predicts' pupils' educational difficulties as well as the variables collected directly from families.

The fact that schools are identified on the basis of their population and not on the zone in which they are located is, above all, due to the lack of sectoring: that each family can freely choose a school means that the pupils do not inevitably attend the school in their sector, and that populations in a school may fluctuate from one year to another. Identification on the basis of the actual school population was chosen because it makes it enables these constraints to be taken into account, to monitor changes in the population of a school and avoid once-and-for-all cataloguing of schools (Demeuse, 2002).

T.-M. Bouchat, B. Delvaux \& G. Hindryckx (2005) note, however, the sometimes debatable character of the way the 'positive discrimination' category is constructed from the administrative standpoint. In addition to the fact that these schools cannot inevitably be identified in the field, they do not form a homogeneous whole by either their population or their context, and do not take in pupils that are clearly more underprivileged than do other schools with an index only just higher than the admission threshold for that category.

\section{The current situation in the French Community of Belgium}

It was the decree dated 24 July 1997 that defined the priority missions for education in the French Community, among which can be found that of providing all pupils with equal opportunity for social emancipation, and preparing pupils for becoming citizens in a society open to other cultures. The Contract for the School, proposed by the Government of the French Community in 2005, also defines political guidelines with its ' 10 priorities for education', including a reassertion of the equality of attainment concerning basic competencies ${ }^{21}$ and a determination to fight against educational segregation. ${ }^{22}$ Concerning priority education policies, various methods may coexist. There are, for example, at least two types of targeting. ${ }^{23}$ Targeting of a linguistic or ethnic nature: pupils are targeted individually because they are from immigrant families or because their native tongue is not the language taught. Socio-economic targeting: allotting additional means to educational sites, and not to the pupils themselves: whatever his/her socio-economic status, a pupil enrolled in the targeted 'positive discrimination' school benefits from additional resources implemented at the level of the site.

\section{Measures based on socio-economic targeting}

\section{Positive discrimination objective and means}

Positive discrimination (and its successor, the ED policy) mainly involves assigning additional resources to identified schools; these additional resources representing approximately 0.45 per cent $^{24}$ of the total teaching budget (with an increase up to 1.35 per cent of the total budget for the ED policy). The objective is to promote educational action in these schools designed to ensure that all pupils have equal opportunity for social emancipation. These additional resources are of three types (decree dated 27 March 2002): 
- $\quad$ human resources assigned in the form of 'teacher-periods' ${ }^{25}$ These resources in practice mean additional teachers. These teachers cannot, however, be granted permanent employment, given the deliberately transitory nature of positive discrimination;

- $\quad$ operating resources, allowing non-teaching staff to be employed (youth workers, social workers, nursery nurses, etc.), equipment to be purchased, cultural or sports activities to be organised and funded, or buildings to be fitted out;

- the modification of certain charts for converting the number of pupils into a number of supervisory staff.

The use of additional teachers is not governed by unbending rules defined on an a priori basis. In fundamental education, the decree dated 27 March 2002 nevertheless specifies that these additional human resources must be used 'in particular to implement differentiated learning' (Article $8,3^{\circ}$ ). It is a little more verbose with regard to secondary education, for which it indicates that the additional supervision must be assigned

in particular when implementing differentiated learning, when making small groups, when organising special courses for pupils who do not speak French, for the prevention of violence, the prevention of dropping-out, remedial classes ... (Article $11,2^{\circ}$ ).

In reality, while the procedure for identifying potential schools that will benefit from the measures is automatic, the assignment of additional means is subject to the introduction and approval of a positive discrimination action project for each school. In other words, while schools do not need to do anything in order to be identified, they must deliver a project if they want to receive additional resources. An action project must therefore be introduced each year. It must include a maximum of three parts, each one specifying an objective to be attained, presenting the concrete actions under consideration over a period of three years, and explaining how the extra budget is assigned and broken down.

The action project approval procedure differs according to the level of teaching. In fundamental education, it is carried out by a 'local commission', released from the segmentation of teaching in networks. In secondary education, the distribution of resources is performed within the teaching networks, but is subject to approval by the government and a central 'positive discrimination commission'. This distribution of resources within the networks may open the door to distributing resources in a way not in keeping with the initial objectives.

To offer a complete picture of socio-economic targeting, and although this measure does not, in our opinion, really come within the scope of the definition of the priority education policies adopted, mention should also be made of the differentiation policy for school funding. This process was set up in 2004 and relates only to allocations that schools receive to cover their various expenditures, in other words their operating resources. It involves using a continuous mathematical formula weighting the assignment of these allocations to the schools according to their average socio-economic index. ${ }^{26}$ 


\section{What action?}

Few scientific studies have attempted to describe the types of action carried out, or teaching practices used, in positive discrimination schools. We are in the context of an educational quasimarket founded on the principle of pedagogical freedom, the consequence of which is little control over results, little control over method, and teaching staff that are unaccountable ${ }^{27}$ for their actions and not very inclined to be evaluated. So it is difficult to know what action has been undertaken in the classroom and to describe or categorise it, not to mention evaluate it. Rey and his colleagues (Coche et al., 2006) may, however, be quoted here. With a view to locating in primary school education those teaching practices that encourage the success of pupils from disadvantaged backgrounds, they studied classes in positive discrimination schools. The aim of this research and the sampling performed do not make it possible to draw any conclusions on the teaching practices being used in positive discrimination schools. T.-M. Bouchat and her colleagues (2005) described the action projects and teaching practices in 12 fundamental positive discrimination schools on the basis of discussions with head teachers. Although most agree that the resources are insufficient and often inadequately assigned, the researchers note certain constant features in the projects:

- $\quad$ remedial work, leading to smaller class sizes, certain classes split into two or 'needs groups';

- $\quad$ social assistance and mediation with the families;

- $\quad$ cultural awakening through excursions;

- $\quad$ the purchase of books and computer equipment.

Among the teaching practices used, they mention work in cycles, ${ }^{28}$ classes grouped together, teachers who 'go up' a level with their class, projects and excursions, the organisation of 'needs groups' according to pupils' difficulties, discussion between teachers or meeting the families in school.

\section{Issues surrounding the definition of the socio-economic index}

In the French Community of Belgium, the positive discrimination policy refuses any ethnic or linguistic targeting: there are other types of targeted policies that deal with the specific needs of these populations. ${ }^{29}$

In the definition of the socio-economic index used within the framework of positive discrimination, taking into account variables referring to nationality is the subject of much debate. These variables were actually deliberately ruled out, both by the legislator and by the inter-university team in charge of calculating the index (Demeuse et al., 1999). When thinking first began on the variables to be taken into account, it was shown that for an equivalent income level, foreigners of various nationalities do not succeed any less than Belgians (Ouali \& Réa, 1994, quoted by Demeuse, 2002), and that while the children of certain nationalities are more prone to educational failure, it is often because they are on average from a less favourable socioeconomic status. In addition, there are many nationalities in the French-speaking area of Belgium, in which great economic as well as linguistic and cultural differences exist. From a 
political point of view, the question of nationality has also been set aside, in order to avoid moral condemnation of populations of immigrant origin, i.e. not to create 'natural' and final categorisation of groups encountering school difficulties de facto. The proportion of pupils of immigrant origin attending a school site is nevertheless an indicator chosen as a detrimental factor for the site, and may be used in determining sites with priority positive discrimination.

The scientific arguments against taking into account migratory origin in setting up a priority education policy are, at the present time, disputed by researchers drawing on the model used in the Flemish Community of Belgium (Jacobs, Réa \& Hanquinet, 2007). These researchers, by counting out the 'socio-economic status' factor of pupils' results provided by the PISA 2003 study, observe that pupils of immigrant origin still obtain lower scores than other pupils. They therefore argue in favour of policies explicitly targeting pupils of immigrant origin. But the results of this study and their interpretation are far from enjoying unanimous backing (Hirtt, 2007).

\section{Measures based on linguistic and/or ethnic targeting}

During the 2004-2005 school year compulsory education in French-speaking Belgium took in a little over 10 per cent of pupils of foreign nationality. Aside from positive discrimination, various structures have been organised to allow these pupils, newly arrived in French-speaking Belgium, and pupils whose native tongue is not French to join the French-speaking Belgian education system to achieve the goals pursued by the 'Missions' decree.

The 'bridge class' (classes-passerelles) measure, adopted in 2001 to counter the difficulties encountered by schools located near refugee candidate centres, was set up to meet the particular needs of newly arrived pupils, or, in other words, refugees or refugee candidates. ${ }^{30}$ The creation of the 'bridge class' structure depends on the number of these pupils within a school. The pupils concerned are grouped together with their pairs and benefit from special teaching for a limited time period, before joining a class corresponding to their level. This structure may be organised only in certain schools, mainly if they are located near a candidate refugee centre. ${ }^{31}$ The fact that the bridge classes are organised within the schools themselves and not in the centres for refugee candidates, and the short amount of time actually spent by the pupils in this system, show a conception of equity towards these children that is like equal access, but which first puts them through a 'passageway', to make effective access easier.

A decree dated 14 June 2001 specifies the competencies aimed at in a bridge class:

- $\quad$ everything that contributes to meeting the general objectives defined (by the Missions decree);

- $\quad$ intensive learning of French for those who do not have a sufficient command of this language;

- $\quad$ suitable remedial training so that the pupil can go back into the appropriate level of studies as soon as possible.

In order to achieve these goals, schools that organise a bridge class receive a little more than the equivalent of one additional teacher. They must submit a report showing that they are really using these additional resources, in particular by means of qualitative and quantitative evaluation of what they are doing towards helping newly arrived pupils to integrate and what guidance they 
are providing. Learning French is the main activity carried out in the bridge class. These 'French as a second language' courses do not meet with any particular need and do not really correspond to learning French as a foreign language, or to mother-tongue French lessons either. They have no particular curriculum, nor any specified methods. Teachers may, however, take a course in teaching French as a second language organised by the in-service training institute (IFC). ${ }^{32}$

The courses for adapting to the language of teaching (ALE) are based on the same idea, but unlike the bridge class, they involve integrating the pupil directly into a class corresponding to their school level, with special language support. This can be organised in each primary school that has at least ten pupils of foreign nationality (or Belgians of foreign origin) who have no command of the language in which lessons are taught. This course is entrusted to a class teacher specialised in helping pupils to adapt in this way. According to the decree dated 13 July 1998, the Government is responsible for evaluating the relevance of this measure every two years.

Finally, in the French Community there is a policy targeting pupils of immigrant origin, but which is not compensatory in nature: the language and culture of origin (LCO) programme, organised by partnership charters signed with Greece, Italy, Morocco, Portugal and Turkey. It allows volunteer schools to host one or more teachers from these countries, with the aim of encouraging children of immigrant origin to integrate into society while safeguarding their original identity, and of helping all pupils to be more receptive to other cultures (the French Community of Belgium, 2007). The programme makes provision for organising lessons in the language and culture of origin, outside school hours and only for the pupils concerned, and also intercultural courses to help all pupils in the class, whether or not they are from the country concerned, to become more receptive to the culture of origin.

\section{What is known about the effects of these policies?}

The quasi-market educational situation and the principle of freedom of teaching, as implemented in French-speaking Belgium, make it difficult, at the present time, to study the effects of the priority education policies. We have only scant information on teaching practices, and there are no outside evaluations relating to all the schools and how they teach. As we are not able to come to a rigorously scientific conclusion about the effects of these practices, we will restrict our conclusions, in this section, to identifying the features of the positive discrimination schools, without being able to allocate them to particular teaching practices.

External, non-certifying evaluations in primary and secondary education make it possible to compare the performances of pupils between positive discrimination schools and the other schools in an overall way. Such a descriptive comparison, taking only this variable into account, was carried out by a working group within the general piloting department of the education system (Ministry of the French Community, 2007). In the second year of general secondary education, the results are scarcely encouraging: pupils in positive discrimination schools do less well in the test, with an average score of 50 per cent, than the other pupils, who on average score 59 per cent. But simply comparing these results from the standpoint of whether the pupil does or does not benefit from positive discrimination does not really make it possible to understand the effectiveness of the measure, since it does not take account the influence of related variables such as the social background of the pupils, and therefore does not allow any ceteris paribus reasoning. 
Evaluations not attempting to study priority education policies can be used to provide another type of answer, albeit one that is not very subtle: in spite of the priority education policies in force in the French Community of Belgium, the ideals of equality of results and equality of social emancipation are a long way from being realised. The 2003 PISA study still shows that the French Community of Belgium has some of the largest variations in results between privileged and underprivileged pupils (Baye et al., 2004). However, it is difficult to determine to what extent, if at all, priority education policies are reducing these variations.

Instructions for following up and evaluating positive discrimination do, nevertheless, exist. The decrees dated 30 July 1998 and 27 March 2002 created a Commission for positive discrimination, responsible, inter alia, for giving recommendations on the implementation of the positive discrimination policy and co-ordinating a three-yearly evaluation plan starting in 2003. The first governmental decree setting up such an evaluation plan is dated 9 June 2004 and gives the following objectives:

- $\quad$ Analyse the impact of the positive discrimination policies on pupils' school careers and results.

- $\quad$ Evaluate the effects these policies have on the image of the schools, the transfer of school populations and the effects on the teaching profession.

- $\quad$ Analyse the process of implementing the projects.

- Examine how the organisations for supervising and assisting positive discrimination work.

- $\quad$ Evaluate the means by which resources are allocated.

Within the framework of this plan, a research report was submitted by T.-M. Bouchat and her colleagues (2005). Their aim was to check the hypothesis that positive discrimination schools are morally condemned by studying school mobility in fundamental education. Many observers in the French-speaking Belgian education system in fact fear that the positive discrimination measure leads to condemnation of the schools that benefit from it, or gives them the image of schools specialised in handling difficult situations. This condemnation of positive discrimination schools could lead other schools to offload their responsibility with regard to the students in difficulty onto them, which would exacerbate school segregation still further.

In fundamental education, at any rate, the results obtained by analysis of the movements of pupils between schools do not seem to confirm the researchers' initial assumption. Firstly, most movement observed between positive discrimination schools and the others takes place between schools close to the threshold at which resources are allocated, i.e. between underprivileged schools. Secondly, the number of pupils moving from positive discrimination schools to other types is not inconsiderable. This observation, in conjunction with the fact that the positive discrimination schools are an important port of entry for non-Europeans, may lead them to be seen as a kind of springboard. The question may consequently be asked as to whether this function taken on by the positive discriminations measure really corresponds to its main mission. The authors can nevertheless conclude from their observations that assigning the positive discrimination label to a school seems less to influence parental strategies than other 
indicators, such as the visible characteristics of the public or the reputation of the school. They observe, finally, that positive discrimination schools provide a significant way of moving towards specialised education. This observation confirms still further the close link between socio-economic background and the move into this type of education.

Other research was centred on how schools are identified for being awarded positive discrimination status by analysing the situation of those schools not on the list but which believe that they should be given additional resources. The results of a study undertaken by M. Demeuse and his colleagues (2006) show firstly the weaknesses of automatic identification by means of the district of origin of the pupils. It appears that the population of the schools studied comes from non-homogeneous districts and does not disperse in a random way throughout the districts, but is concentrated mainly in certain streets. However, this observation runs up against the absence of statistical data at a level lower than that of the district and that can be used to identify schools benefiting from positive discrimination status. As in the study by T.-M. Bouchat et al. (2005), this study calls for thinking to be continued as to how resources can be allocated on the basis of a continuous function and not on that of the current dichotomous mechanism.

The study by M. Demeuse et al. also looks at formalising new objective indicators in decisions regarding additional schools being listed as having positive discrimination status. The conclusions of this study recommend taking into account pupils' mobility and absenteeism, and the internal and external backwardness ${ }^{33}$ of the schools. In this way, it could be considered that a school in which enrolments are late, in which absenteeism is high and in which most pupils are already lagging behind those in other schools, should be able to benefit from additional resources. Taking these last two indicators into account raises several questions, however. Should schools where pupils are often absent be 'rewarded'? Should a financial advantage be awarded to schools taking in pupils who are already lagging behind those in other schools without penalising the latter schools, at the risk of having selective schools offload their students in difficulty to other schools that would be 'paid' to look after them?

It will be seen that one of the most important problems facing the education system of the French Community is the large amount of segregation that remains within it. The government is well aware of this problem, and, via the Contract for the school published in 2005, has shown itself determined to come to grips with it. The priority education policies currently in force do not solve this problem. It will be noted on this subject that they are designed with a view to compensate for, and not to fight against, segregation. M. Demeuse (2002) also shows that groups of pupils within schools may exist, such as level classes or separation between courses. In the same way, the large degree of educational mobility in the French Community remains a factor leading to segregation, and makes it difficult to draw up reliable, up-to-date statistics for allocating additional resources. Little is in fact currently known about the specific impact that the positive discrimination policy may have had on educational segregation.

\section{Flemish Community}

Despite more than 25 years of separation between the education systems of the language communities, many similarities persist, even in recent measures aimed at addressing educational priority objectives. We will not, therefore, discuss all the Primary Education Policy (PEP) measures of the Flemish Government in depth. Let us just mention, for the sake of completeness, measures such as 'bridging classes', Dutch as a second language courses, education in the mother tongue and home culture for immigrants, or inclusive education for children with special 
needs, without entering into a detailed analysis. In what follows, we will discuss the key programmes that have been successively introduced since the late 1980s.

\section{Priority education policy for children from an immigrant background}

The first measure relating to PEPs in Flanders dates back to 1989, when educational priority areas were established in the Province of Limburg, in a context of economic restructuring. As the coal mining industry went bankrupt and the government decided to stop subsidising it, a 'social investment trust' was created, whose remit was to help the region remedy the social consequences of the closure. One of the priorities of the trust was to raise the educational attainment of children in five municipalities with a high concentration of immigrant workers (most of whom were employed in the coal mines).

At the level of the Flemish Community, a more generic Priority Education Policy came into effect in 1991. This policy was targeted at pupils from (relatively disadvantaged) immigrant families $^{34}$ across Flanders, in primary and secondary education. Schools were granted additional funding for each target group pupil beyond a minimum threshold, provided they could clearly indicate in a utilisation plan how they intended to spend these resources. Three broad priorities were prescribed:

- $\quad$ the pupils' command of the Dutch language;

- $\quad$ prevention and remediation of learning and developmental problems;

- $\quad$ involving parents in the education process, for example through school community action.

A scientific evaluation of the PEPs for immigrants started after two years of operation (Vanhoren et al., 1995). In this evaluation, the critical success factors and the initial effects on the learning progress of the target group were investigated.

Only in the third year of operation was significant progress observed in the implementation of the innovations. With the increasing availability of didactic materials and experience in the schools, the process had acquired its own momentum and in most of the schools innovations were being implemented in all three fields of activity. At all educational levels the 'command of the language' priority turned out to be the most fully developed field of action. One of the reasons for this was the fact that its importance was accepted by all parties and that specific materials had been made available for it. Further, intensive support by an external expert, who at the same time was accepted by the school team, appeared to be of key importance in the introduction and implementation of innovations. Finally, a well-functioning core team of teachers operated as a motor for co-ordinating innovations, transferring them to the entire school level and keeping them going.

The effects of PEPs on educational performance have been checked only for the regular primary education system (Schrijvers et al., 2002). This was done by testing the language and arithmetic skills of some 1500 PEP and non-PEP pupils at different points during the second/third and fourth/fifth grades, respectively. From a methodological point of view, this approach cannot be considered very valid, as no comparison could be made with the performance gap(s) before the implementation of PEPs. Nevertheless, the evaluation pointed out 
that the performance gap between the native and immigrant pupils increased steadily in the fourth grade compared with the second grade. Here, even the pupils from Southern Europe no longer scored significantly better than the North African pupils. Regression analysis was then used to check whether significant differences in progression could be observed between PEP and non-PEP schools. The results were negative. ${ }^{35}$ Depending on the test applied or the study year, the effects of the implementation characteristics studied (implementation level of the different fields of intervention) varied in different directions.

\section{Extended care}

In 1993 a legal framework for Extended Care was introduced into the primary education system. Under certain conditions, this policy enabled schools to obtain extra staff and resources to develop an educational approach geared to the specific needs of children (poor and non-poor, native as well as immigrant) with 'social, emotional and learning problems'. These funds must be used for additional educational staff and activities in the transition period from nursery (mainly 3rd year) to primary school (1st year).

Despite criticism about the vague definition of target groups, practice focused mainly on pupils from underprivileged families. After five years of operation, the Department of Education also imposed some precise socio-economic criteria to define the target group: children with poorly educated mothers, children from jobless households and/or from single-parent families. Schools could submit action plans for the implementation of four objectives:

- $\quad$ at the level of school organisation: broadening the range of materials and activities available to the pupils and developing multidisciplinary consultation;

- $\quad$ at the level of the class: working on differentiation and individualisation;

- $\quad$ introduction of a pupil monitoring system;

- $\quad$ developing support for developmentally endangered children and children with socioemotional problems.

Evaluation of the Extended Care practice in schools has yielded mixed findings. Bollens et al. (1998) found a significant positive effect of the number of teacher-hours spent on Extended Care on learning progress in the first two grades of primary school. However, it also appeared that schools were now able to detect learning problems earlier, but were unable fully to prevent or remedy such problems: the proportion of children referred to special education increased (and has kept increasing until today), despite the fact that the reduction of referrals was among the primary objectives of Extended Care (Ruelens et al., 2001; Van Heddegem, Douterlungne \& Van de Velde, 2003). This suggests that the additional resources were insufficient to remedy problems. Moreover, a mere quantitative investment may yield unsatisfactory results if it is not accompanied with better (initial as well as in-service) training of teachers.

All in all, both Priority Education Policy and Extended Care failed to reduce educational disadvantage in any substantial way. They seem to have contributed to a better understanding of problems, without resolving them across the board. This is quite understandable, taking into 
account that the budget invested in both policy strands together did not exceed 1 per cent of the overall education budget.

\section{The Equal Educational Opportunities (EEO) Act}

As from 2002, PEP and Extended Care were merged into a single, more ambitious framework, which is still operational today. The new law introduced several innovations.

First of all, the targeting of resources is now based on objective and measurable criteria: ${ }^{36}$ the number of poorly educated mothers, jobless households, travelling households, children placed in institutional or foster care, and non-Dutch speaking households. ${ }^{37}$ All these criteria refer to the socio-economic background of pupils, which means a shift of emphasis to a more social and preventive approach. For this purpose, an extensive registration and control system has been developed at pupil level.

In order to minimise the paperwork, the needs of schools are measured every three years and the additional funding is kept constant for the same period. Moreover, the specific EEO funding has been increased to 4 per cent in basic education. ${ }^{38}$

The third innovation in EEO is the increased autonomy of schools in setting their own priorities. Schools are now supposed to analyse the context at the start of every three-year cycle, and to evaluate their own progress, using their own criteria, during the cycle. The inspectorate mainly evaluates the effects by the end of the third year and thus establishes whether schools are allowed to apply for further extra funding in the next period. Whereas a 'menu' of recommended actions is still provided by the Government, schools are given more degrees of freedom as they need to select one of three priority fields, supplemented with their own priorities. The three priorities put forward by the law include: preventing and remedying learning/behavioural problems; developing language skills; and boosting pupils' self-confidence and independence in determining their educational career.

The financial weighting of students occurs as follows: pupils who meet the criteria listed above are given an additional weighting which varies between 0.4 and 1.2 , depending on the nature and cumulation of indicators of disadvantage. Figures 3.2 and 3.3 below give an idea of the actual funding per pupil in primary and secondary schools, respectively - in relation to the proportion of target group pupils within the school population. 


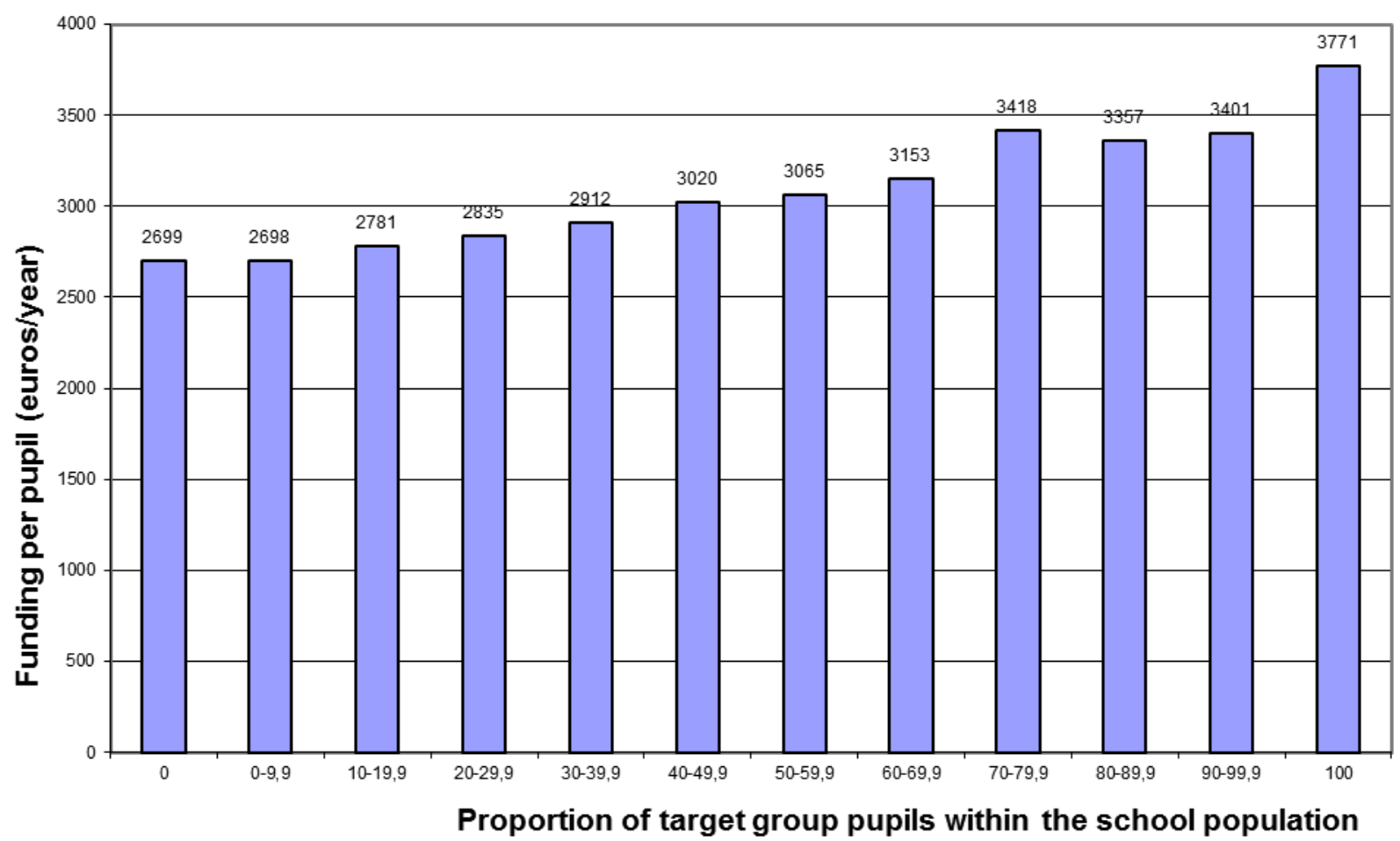

Figure 3.2. Public funding per pupil ( $€$ /year) in Flemish primary education, school year 20072008 , by share of EEO target group.

(Source: Department of Education). 


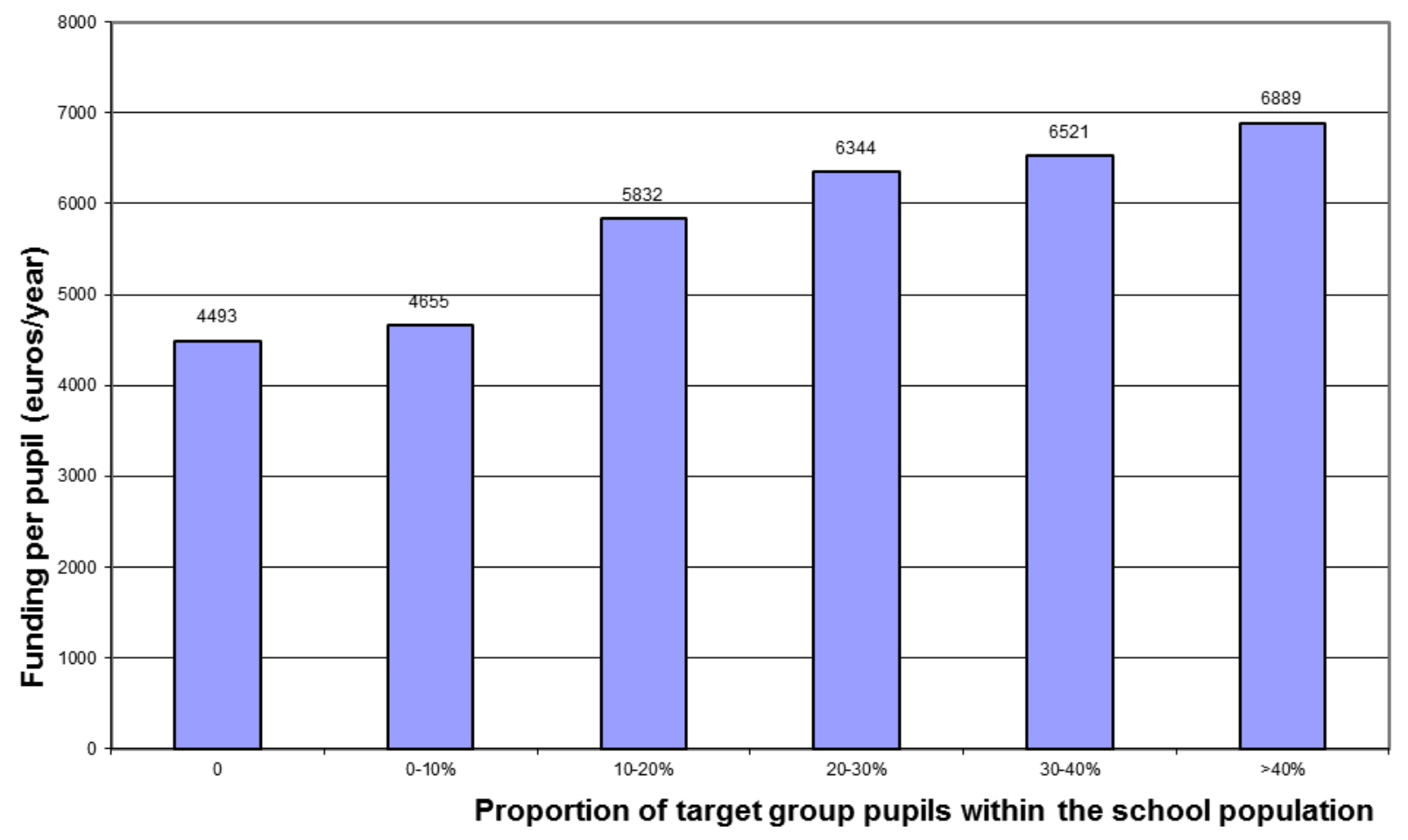

Figure 3.3. Public funding per pupil ( $€$ /year) in Flemish secondary education, school year 20078 , by share of EEO target group.

(Source: Department of Education).

Several qualifications must be borne in mind in interpreting these figures. To begin with, the share of the target group is seldom higher than 60 per cent in primary schools. This means that a concentration school (with 50-60 per cent disadvantaged pupils) gets, on average, 14 per cent more per pupil than a 'white' school. ${ }^{39}$ There is a general consensus that this does not fully compensate for the additional 'burden' on the former type of school.

Secondly, the actual differences in funding are only partly driven by the EEO funding as such. This is most flagrant in (upper) secondary education, where the EEO budget is minimal compared with regular subsidies. The main reason why Figure 3.3 shows an increasing pattern is the underlying correlation between social background and educational career paths: most disadvantaged students end up in vocational schools, which benefit from higher teacher-student ratios. It is unclear to what extent these higher ratios are justified by technical or organisational arguments (such as the need to split into smaller groups for practical subjects). Some insiders believe that the better staffing in vocational schools can also be seen as a PEP measure - 'avant la lettre'. Whatever the explanation may be, the present redistribution effect appears to be more intimately connected with social stratification mechanisms (tracking of disadvantaged students to vocational schools) than with the proper social background of students. In fact, this means that disadvantaged students are better funded only if they opt for vocational careers - which obviously goes against the spirit of PEP. 
After five years of operation (2002-2007), broadly speaking, all parties tend to agree that the EEO Act has contributed to further improvements in the professionalism of teachers and the schools' capacity to manage their social policy. However, some problems have been identified that motivate further reforms.

First of all, there is some dissatisfaction about the paperwork involved in assessing the needs of schools. A dilemma between target effectiveness and complexity characterises the present legislation. Evaluation research had demonstrated that, even when resources are aggregated at the school level, the use of geographical or 'approximate' indicators resulted in a substantial margin of error in targeting resources (Bollens et al., 1998). ${ }^{40}$ This explains why a rather complex individual registration system has been developed. Nevertheless, some parents have criticised the intrusive nature of the questionnaires concerning their social background. At the same time, schools complain about the burden of the paperwork, and the ministry is suspicious about the fraud sensitiveness of the system, as the number of subsidised students tends to increase. An expert group is currently examining whether individual electronic records owned by the government, such as census data or data on students benefiting from student grants, can yield similar information with the same degree of precision and without necessitating extensive paperwork. The Department of Education should be able to link existing electronic information concerning individual students and their parents to the school attended by each student.

One of the key issues in defining the target group(s) relates to ethnicity. Given the wide gap in educational performance between native and immigrant youth, it is essential to target EP funding at the latter (second-generation Moroccan and Turkish youth in particular). However, unlike countries such as the UK, Belgium has no tradition of registering information about citizens' ethnic background. Moreover, in a climate of fairly strong xenophobia, the Flemish Government is reluctant to prioritise immigrants. Language would be a straightforward alternative, but this is not evident in a trilingual country. ${ }^{41}$ Additional subsidies for non-Dutch speaking students would also favour high-socio-economic status, French-speaking Belgian students. ${ }^{42}$ This issue is as yet unsettled. Research has emphasised the necessity of specific measures for children with an immigrant background, as their underachievement can not be explained by socio-economic characteristics alone (Hirtt, 2006).

Most importantly, experts and policy makers agree that a more powerful redistribution is needed in the funding per pupil, in order to make a decisive impact on equal educational opportunities. Not only should more weight be given to SES criteria, but the funding should also be (partly) disconnected from the present tracking system in secondary education: disadvantaged students should also be better subsidised if they manage to remain in general or technical education. In other words, a shift needs to be made from study field-related criteria to studentrelated criteria.

\section{Towards a structural reform}

The ambition of the present Flemish Government is to carry through such a structural reform, starting gradually from 2008, in which pupil characteristics were awarded greater weighting in the distribution of resources among schools. The objectives of the reform are twofold: firstly, subsidies differentiated by social background aim to compensate for the higher cost involved in teaching students from lower socio-economic strata. In this way, the latter will receive betterquality education and will hopefully be able to overcome social obstacles. And secondly, the differentiated funding should make low-SES students more attractive to schools, and thus 
attenuate the selectivity of schools in the 'quasi-market' environment that characterises the Belgian educational landscape.

The present context is quite favourable for such a reform, as overall subsidies per pupil are on the increase: in such a context, it is politically more feasible to redistribute resources.

Not only will the system become more redistributive, according to the social mix within schools, but the redistribution will also be mainstreamed, as the EEO funding will no longer be separated from the regular funding mechanisms. Apart from the overall budget increase, some shifts will also be operated to attenuate the 'tracking' of students (by reducing the differences between general, technical and vocational education) and to encourage economies of scale in secondary education. Public and private schools will also be funded on an equal footing. It goes without saying that such a comprehensive reform involves considerable negotiation and strategic analysis.

\section{Conclusions and perspectives}

Throughout this chapter, we have looked at the similarities and the differences in priority education policies of two of the three Belgian education systems. The policies set up on both the Dutch-speaking and the French-speaking sides try mainly to counter the major inequalities that are largely due to the educational quasi-market. While policies such as 'positive discrimination' in the French Community and the Equal opportunity in education in the Flemish Community consist above all of a modulated assignment of resources to the schools, they are different in the way they target pupils.

In keeping with research results (Bollens et al., 1998), the Flemish Community chose direct, but voluntary, data collection in the schools, but is confronted today with problems of the protection of private life, administrative complexity and sensitivity to fraud. The French Community, also basing its actions on research results (Demeuse, 1996; Demeuse \& Monseur, 1999), opted for indirect data collection based on pupils' place of residence, and has not therefore encountered the same problems as the Flemish community. But this indirect measurement poses problems of fine targeting in certain districts, mainly in the urban environment.

On a more basic level, the French and Flemish communities are notably different in the way they define the population targeted by priority education policies. On the one hand, in the French Community, action taken to deal with a linguistic disadvantage is clearly separated from action on a socio-economic disadvantage, even though the various policies may relate to the same schools. Taking into account information on nationality or the language spoken at home is systematically ignored, both by researchers and decision makers, in regard to the positive discrimination policy. In contrast, in the Flemish Community, this information concerning language is included in the identification of populations targeted by the Equal opportunity in education policy. In this context, while researchers have also identified ethnically based target groups (Turkish and Moroccan second-generation immigrants) for which additional resources should be provided, the decision makers continue to have reserves with regard to priority measures likely to worsen the climate of xenophobia reigning in the north of the country.

The Belgian educational quasi-markets are the cause of inequalities, and also create difficulty in any serious evaluation of the effects of priority education policies. In the French Community, in the absence of any currently usable data on external evaluations, the 
effectiveness of the positive discrimination measures cannot truly be estimated. As for their effects as a system, in particular the fear that the schools benefiting from the measure would be condemned, these have been tempered in the case of fundamental education (Bouchat et al., 2005). In the Flemish Community, the effects of Priority teaching and Extended care have been evaluated and found wanting. The Equal opportunity in education policy, with its objective targeting, larger budget and autonomy granted to the schools, aims to be more ambitious. It is nonetheless difficult to evaluate its effects, firstly because additional subsidies are associated with an unfavourable context in the targeted schools and therefore their net effect cannot really be isolated. Secondly, since the additional funding is identical in all schools with an identical public (within the same community), it is almost impossible to define a control group that would be an exception to the rule. The main question posed by priority education policies in Belgium is that of educational segregation. In an educational quasi-market characterised by a system of courses that are not perceived as being of equal value, for a socially marked and diversely financed public, significant relegation and segregation mechanisms come into being. There is currently nothing to counter these: the priority education policies were drawn up not as an incentive for social diversity, but from a compensatory point of view. Without claiming that social diversity alone would entirely solve the problems of educational inequality, it does appear essential to take action on the segregation phenomena that accentuate them. So in both the French and the Flemish communities, the move is towards the development of policies that encourage greater social diversity by regulating the quasi-market. The question may be asked as to whether the objective of social diversity could not be attained by measures other than the additional subsidies granted as a result of the priority education policies. If need be, these more efficient (because they are less expensive) alternatives would undoubtedly deserve to be implemented first, taking into account not symptoms, but causes.

In the Flemish Community, the Equal opportunity in education decree also contains a ruling aimed at limiting the concentration of underprivileged people in ghetto schools. When that concentration is 10 per cent above the average for schools in the area, the school concerned can legally give priority to candidates coming from more privileged backgrounds. This ruling was revised several times since it came into effect in 2002, and it remains disputed: a thorough evaluation of its effects would be welcome.

In the French Community, two academic prospective studies ${ }^{43}$ have been carried out in this direction, rooted in a conception of equity as equality of social realisation. The first (Delvaux et al., 2005) studies the feasibility of the creation of 'school catchment areas' in which the schools could work in collaboration whatever their network, especially from the point of view of the teaching offer. It also proposes a system of collective treatment of preferences in choosing schools, in order to further regulate the quasi-market, while respecting parents' freedom of choice. The authors believe that such actions could limit the phenomenon of educational segregation and provide all pupils with equal opportunities for social realisation. The various tensions arising from these proposals do, however, make it difficult to continue along this path.

A second study (Demeuse et al., 2007) considers the possibility of a way of funding schools according to a general formula for allocating resources according to needs (Ross \& Levacic, 1999) based on objective indicators including socio-economic indices, but also on information of an educational nature, such as taking into account the external backwardness handled by each school. ${ }^{44}$ Such a formula could be used to encourage schools to be less selective, while allocating additional resources to those schools in difficulty. It could also replace the 
dichotomous positive discrimination mechanism by a form of distribution that is modulated according to a continuous function. Nevertheless, it still runs up against certain perverse effects of incentives and penalisation in a system primarily governed by the law of the market.

\section{Bibliography}

\section{Scientific documents}

Aubert-lotarski A., Demeuse M., Friant N. \& Derobertmasure A. (2007). 'Conseiller le politique: des évaluations commanditées à la prospective en éducation' [Advising the politician: evaluations commissioned from educational research]. Les Dossiers des Sciences de l'Éducation, no. 18 , pp. 121-130.

Baye A., Demonty I., Fagnant A., La Fontaine D., Matoul A. \& Monseur C. (2004). 'Les compétences des jeunes de 15 ans en Communauté française de Belgique en mathématiques, en lecture et en sciences. Résultats de l'enquête PISA 2003' [The competencies of fifteen-year olds in the French Community of Belgium. Results of the PISA 2003 survey]. Les Cahiers du Service de pédagogie expérimentale, no. 19-20.

BECKERS J. (2006). Enseignant en Communauté française de Belgique: mieux comprendre le système, ses institutions et ses politiques éducatives pour mieux situer son action [A teacher in the French Community of Belgium: gaining a better understanding of the system, its institutions and its educational policies to gain a better grasp of ones role in the system]. Brussels: De Boeck.

Björklund A., Edin P. A., Frederiksson P. \& Krueger A. (2006). The market comes to education in Sweden. An analysis of Swedish school reforms during the 1990s. New York: Russell Sage Foundation.

Bollens J., Van de Velde V., Cnudde V., Vanobbergen B., Vansieleghem N., Douterlungne M., NiCAise I. \& Verhaeghe J.-P. (1998). Zorgverbreding in het basis-en secundair onderwijs: een zoektocht naar financieringscriteria [Reinforced supervision in basic and secondary education: looking for funding criteria]. Louvain: HIVA/RUG, Vakgroep Onderwijskunde.

Bouchat T.-M., Delvaux B. \& Hindryckx G. (2005). Discrimination positive et mobilité scolaire. Rapport de recherche remis à la Communauté française dans le cadre du plan d'évaluation des politiques de discrimination positive. [Positive discrimination and educational mobility. Research report delivered to the French Community in the context of the evaluation scheme for positive discrimination policies]. Unpublished research report.

BRADlEy S. \& TAYLOR J. (2000). The effect of the quasi-market on the equity-efficiency tradeoff in the secondary school sector. Working Paper no. 2000/008. Lancaster: Lancaster University Management.

Carroll J. B. (1963). ‘A model of school learning'. Teachers College Record, 64, pp. 723-733.

Coche F., Kahn S., Robin F., Rey B. \& Genot P. (2006). Pratiques pédagogiques à l'école primaire et réussite des élèves venant de milieux défavorisés [Educational practices in the 
primary school and success of children from underprivileged backgrounds]. A research report available on the website of Enseignement en Communauté française de Belgique: $<$ http://www.enseignement.be/@librairie/documents/ressources/110/rapfin_2006.pdf $>$ (consulted on 3 July 2008).

CONSEIL DE L'ÉdUCATION ET DE LA FORMATION (CEF) (1994). La discrimination positive, moyen de favoriser la réussite scolaire des enfants issus de milieux défavorisés [Positive discrimination as a means for encouraging academic success in children from underprivileged backgrounds] (16 September 1994). Brussels: Communauté française de Belgique, Conseil de l'éducation et de la formation. Document available on the CEF website: $<$ http://www.cefcfwb.be/biblio_file_get.phpPdf_id=67\&df_check=> (consulted on 3 July 2008).

Delvaux B., Demeuse M. \& Dupriez V. (2005). 'En guise de conclusion: encadrer la liberté' [By way of conclusion: managing freedom]. In M. Demeuse, A. Baye, M. H. Straeten, J. NicAise \& A. MATOUL (éds.), Vers une école juste et efficace. Vint-six contributions à l'analyse des systèmes d'enseignement et de formation. [Towards fair and efficient schooling. Twenty-six contributions to the analysis of education and training systems]. Brussels: De Boeck.

Delvaux B., Demeuse M., Dupriez V., Fagnan A., Guisset C., Lafontaine D., Marissal P. \& Maroy C. (2005). Les bassins scolaires: de l'idée au projet. Propositions relatives aux domaines d'intervention, aux instances et aux territoires. [School catchment areas: from idea to project. Proposals on scope, authorities and regions]. Research report available on the FTP server of the Institut d'administration scolaire - Université de Mons-Hainaut: <ftp://ftp.umh.ac.be/ pub/ftp_inas/bassins> (consulted on 3 July 2008).

DEMEUSE M. (1996). Mise au point d'un dispositif d'évaluation des performances "objectives » des établissements scolaires dans l'enseignement fondamental de la Communauté française [Developing an 'objective' system for evaluating the performance of schools in basic education in the French Community]. Final report - Phase III. Liège: Université de Liège, Service de pédagogie expérimentale. Unpublished report.

Demeuse M. (2000). 'La politique de discrimination positive en Communauté française de Belgique: une méthode d'attribution des moyens supplémentaires basée sur des indicateurs objectifs [The positive discrimination policy in the French Community of Belgium: a method for allocating additional resources based on objective indicators]'. Cahiers du Service de pédagogie expérimentale, nos. 1-2, pp. 115-135.

Demeuse M. (2002). Analyse critique des fondements de l'attribution des moyens destinés à la politique de discrimination positive en matière d'enseignement en Communauté française de Belgique [Critical analysis of the fundamentals of allocating resources for the positive discrimination policy in the French Community of Belgium]. Doctoral thesis, psychological sciences, Liège University.

Demeuse M. (2005). 'La marche vers l'équité en Belgique francophone [In pursuit of equity in French-speaking Belgium]'. In M. Demeuse, A. Baye, M. H. Straeten, J. Nicaise \& A. MAtoul (éds.), Vers une école juste et efficace. Vingt-six contributions à l'analyse des systèmes 
d'enseignement et de formation [Towards fair and efficient schooling. Twenty-six contributions to the analysis of education and training systems]. Brussels: De Boeck, pp. 191-216.

Demeuse M., Crahay M. \& Monseur C. (2001). 'Efficiency and equity'. In W. Hutmacher, D. Cochrane \& N. BotTANi (eds), In pursuit of equity in education. Using international indicators to compare equity policies. Doordrecht: Kluwer, pp. 65-91.

Demeuse M., Crahay M. \& Monseur C. (2005). 'Efficacité et équité dans les systèmes éducatifs. Les deux faces d'une même pièce?' [Efficiency and equity in education systems. Two sides of the same coin?]. In M. Demeuse, A. BAye, M. H. Straeten, J. Nicaise \& A. Matoul (eds.), [Towards fair and efficient schooling. Twenty-six contributions to the analysis of education and training systems]. Brussels: De Boeck Université (Economie, Société, Région), pp. 391-410.

Demeuse M., Derobertmasure A., Friant N., Herremans T., Monseur C., Uyttendaele S. \& VERDALE N. (2007). Étude exploratoire sur la mise en œuvre de nouvelles mesures visant à lutter contre les phénomènes de ségrégation scolaire et d'inéquité au sein du système éducatif de la Communauté française de Belgique [Exploratory study on implementing new measures in the fight against educational segregation and inequity within the education system of the French Community of Belgium]. Brussels: Gouvernement de la Communauté française de Belgique (unpublished research report).

Demeuse M. \& Lafontaine D. (2005). 'L'orientation scolaire en Communauté française de Belgique' [School guidance in the French Community of Belgium]. Revue internationale d'éducation de Sèvres, no. 38, pp. 35-51.

Demeuse M., Lafontaine D. \& Straeten D. (2005). 'Parcours scolaire et inégalités de résultats' [School career and unequal results]. In M. Demeuse, A. BAYE, M. H. Straeten, J. NiCAise, A. MATOUL (eds), Vers une école juste et efficace. 26 contributions sur les systèmes d'enseignement et de formation [Towards fair and efficient schooling. Twenty-six contributions to the analysis of education and training systems]. Brussels: De Boeck Université (Economie, Société, Région), pp. 259-273.

Demeuse M. \& Monseur C. (1999). 'Analyse critique des indicateurs déterminant l'attribution des moyens destinés à la politique de discrimination positive en Communauté française de Belgique' [Critical analysis of the indicators determining the allocation of resources for the positive discrimination policy in the French Community of Belgium]. Mesure et Évaluation en Éducation, 22, nos. 2-3, pp. 97-127.

Demeuse M., Monseur C., Collard A., Marissal P., Van Hamme G. \& Delvaux B. (1999). La détermination des quartiers devant être pris en compte pour l'établissement de la liste des établissements et implantations à discrimination positive [Determining the districts to be taken into consideration in drawing up the list of positive discrimination establishments and sites]. Inter-university study commissioned by the Ministry of the French Community of Belgium in the framework of the decree dated 30 June 1998 aiming to ensure that all pupils have equal opportunity for social emancipation, especially for the implementation of positive discrimination 
measures. Unpublished report delivered to the government of the French Community of Belgium.

Demeuse M. \& NiCAISE J. (2005). 'Discriminations et actions positives, politiques d'éducation prioritaire... vers une rupture de l'égalité formelle en éducation' [Discrimination and positive action, priority education policies... towards a break with formal equality in education]. In M. Demeuse, A. Baye, M. H. Straeten, J. Nicaise \& A. Matoul (eds), Vers une école juste et efficace. Vingt-six contributions à l'analyse des systèmes d'enseignement et de formation [Towards fair and efficient schooling. Twenty-six contributions to the analysis of education and training systems]. Brussels: De Boeck, pp. 233-257.

Demeuse M. ET AL. (2006). 'Behind positive discrimination in the French Community of Belgium: central criteria vs. local actions'. In L. Moreno HerRerA, G. JONES \& J. RANTALA (eds.), Enacting equity in education: Towards a comparison of equitable practices in different European local contexts. Helsinki: Research Center for Social Studies in Education - University of Helsinki.

De Winter L., Dierynck R., Gommers E., Meeusen S., Van de Velde J., Verhesschen P., VAN DEN BERGHE R. \& SMEYERS P. (1997). OVGB: een uniek samenspel met vele partners. Evaluatie van het onderwijsvoorrangsgebiedenbeleid in Limburg [Priority education zone policy: coordination of multiple partners. Evaluating priority education zones in Limbourg]. Louvain: Centrum voor Onderwijsbeleid en - vernieuwing, Université catholique de Louvain.

DupriEZ V. \& DumAY X. (2006). 'Élèves en difficulté d'apprentissage: parcours et environnements éducatifs différenciés en fonction des structures scolaires' [Pupils with learning difficulties: educational careers and environments differentiated according to school structures]. Les Cahiers de la recherche en éducation et formation, no. 51.

Dupriez V. \& VAndenberghe V. (2004). 'L'école en Communauté française de Belgique: de quelle inégalité parlons-nous?' [Schooling in the French Community of Belgium: what kind of inequality are we talking about?]. Les Cahiers de recherche en éducation et formation, no. 27.

ETNIC (Entreprise des technologies nouvelles de l'information et de la communication) (2006a). Statistiques de l'enseignement de plein exercice et de promotion sociale (2005-2006) [Statistics on full time and in-service education (2005-2006)]. Document available on the ETNIC website: $<$ http://www.statistiques.cfwb.be/publicationsDetails.php $>$ (consulted on 3 July 2008).

ETNIC (2006b). Les indicateurs de l'enseignement, numéro 1, édition 2006 [Indicators of Education, number 1, 2006]. Electronic document available on the website of Enseignement en Communauté française de Belgique: $<$ http://www.enseignement.be/prof/dossiers/indicateurs/index.asp> (consulted on 3 July 2008).

EURYDICE (2004). L'intégration scolaire des enfants immigrants en Europe. BelgiqueCommunauté française [Educational integration of immigrant children in Europe]. Electronic document available on the website: $<$ http://www.eurydice.org/ressources/eurydice/zip/0_integral/044FR.zip> (consulted on 3 July2008). 
EURYDICE (2005). Chiffres clés de l'éducation en Europe 2005 [Key figures for education in Europe 2005]. Luxembourg: Office des publications officielles des Communautés européennes.

GRISAY A. (1984). 'Quels indicateurs pour quelle réduction des inégalités scolaires?' [What indicators for what reduction in educational inequality?]. Revue de la Direction générale de l'organisation des études (Brussels), no. 9, pp. 3-14.

Grootaers D. (1998). Histoire de l'enseignement en Belgique [A history of teaching in Belgium]. Brussels: Éditions du Centre de recherche et d'information sociopolitiques (CRISP).

HIRTT N. (2002), 'Marchés scolaires, filières, sous-financement: la catastrophe scolaire belge' [Educational markets, courses of study, under-funding: the Belgian educational catastrophe]. L'École Démocratique, no. 9.

HiRTt N. (2006). PISA 2003 et les mauvais résultats des élèves issus de l'immigration en Belgique. Handicap culturel, mauvaise intégration, ou ségrégation sociale? [PISA 2003 and the poor results obtained by children from immigrant backgrounds. Cultural handicap, poor integration or social segregation?] Brussels: Aped.

HiRtT N. (2007). Performances scolaires des élèves allochtones et origine sociale: notes marginales auprès du rapport de la Fondation Roi Baudouin [Academic performance of nativeorigin pupils and social origin: marginal notes to the report by the Fondation Roi Baudoin]. Electronic document available on the Aped website: $<$ http://www.ecoledemocratique.org/IMG/pdf/Discussion_FRB.pdf $>$ (consulted on 3 July 2008).

JACOBS D., RÉA A. \& HANQuinet L. (2007). Performances des élèves issus de l'immigration en Belgique selon l'étude PISA. Une comparaison entre la Communauté française et la Communauté flamande [Performance of children from immigrant backgrounds in Belgium according to the PISA study. A comparison between the French Community and the Flemish Community]. Electronic document available on the Fondation Roi Baudouin website: $<$ http://www.kbs-frb.be/uploadedFiles/KBS-FRB/Files/FR/PUB_1665_E\&JA_PisaFr.pdf $>$ (consulted on 3 July 2008).

Maroy C. \& Delvaux B. (2006). 'Multirégulation et logique de quasi-marché: le bassin de Charleroi en Belgique' [Multi-regulation and the quasi-market logic: the Charleroi region in Belgium]. In C. MAROY (ed.), École, régulation et marché: une comparaison de six espaces scolaires locaux en Europe. Paris: Presses universitaires de France, pp. 315-351.

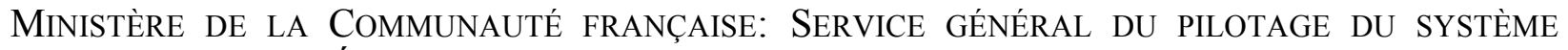
ÉDUCATIF (2007). Évaluation externe non certificative, deuxième année de l'enseignement secondaire: lecture et production d'écrit: résultats et commentaires [Non-certifying outside evaluation, year two of the secondary school: reading and writing: results and comments]. Electronic document available on the website of the Ministry of the French Community of Belgium: <http://www.enseignement.be/@librairie/documents/outileval/evalext/2007_2SRC.pdf $>$ (consulted on 3 July 2008).

Ross K. N. (1983). Social area indicators of educational need. Hawthorn (Victoria): Australian Council for Educational Research. 
Ross K. N. \& LeVACIC R. (1999). Needs-based resource allocation in education. Paris: International Institute for Educational Planning.

Ruelens L., Dehandschutter R., Ghesquière P. \& Douterlungne M. (2001). Op de wip. De overgang van het gewoon naar het buitengewoon basisonderwijs: analyse van de verwijzingspraktijk in Centra voor Leerlingenbegeleiding [The bird on the branch. Transitions from basic education to specialized education: analysis of reference practices in pupil support centres]. Louvain: HIVA.

SchriJVers E., Hillewaere K., VAN DE Velde V. \& Verlot M. (2002). Evaluatieonderzoek van het onderwijsvoorrangsbeleid [Research-evaluation of the priority education policy]. Louvain: HIVA.

VAN HAECHT A. (1985). L'enseignement rénové de l'origine à l'éclipse [Renovated education from its beginnings to its eclipse]. Brussels: Éditions de l'université de Bruxelles.

VANDENBERGHE V. (1996). Functioning and Regulation of Eductional Quasi-Markets. Louvainla-Neuve: CIACO (New series, no. 283).

VANDENBERGHE V. (2000). 'Enseignement et iniquité: singularité de la question en Communauté Wallonie-Bruxelles [Education and iniquity: a singular question in the Walloon-Brussels Community]'. Les Cahiers de recherche du GIRSEF, no. 8.

Van Heddegem I., Douterlungne M. \& Van de Velde V. (2003). Mag het iets méér zijn? Evolutie van het project zorgverbreding in het basisonderwijs [Can one ask for a little more? Development of the 'extended care' project in basic schooling]. Louvain: HIVA.

VAnhoren I., VAn de Velde V. \& RAmakers J. (1995). De evaluatie van het onderwijsbeleid voor migranten [Evaluation of education policies in favour of immigrant populations]. Louvain: Hoger Instituut voor de Arbeid.

Legal references and official documents

BelgiQue (1959). Law dated 29 May 1959 modifying certain provisions of the legislation relating to teaching (Moniteur: 19 June 1959).

Communauté Française de BelgiQue (2007). Circularn ${ }^{\circ} 1841$ dated 18 April 2007 pertaining to the language and culture of origin. Document available on the website of the French Community of Belgium: <http://www.adm.cfwb.be/index.php?m=doc_view\&do_id=2028> (consulted on 4 July 2008).

Gouvernement de la Communauté Française de Belgique (1995). Decree dated 14 March 1995 pertaining to the promotion of a school for success in fundamental schooling (Moniteur: 17 August 1995).

Gouvernement de la Communauté FranÇAise de BelgiQue (1997). Decree dated 24 July 1997 defining the priority missions of fundamental and secondary education and providing the organisation required to carry these out (Moniteur: 23 September 1997). 
Gouvernement de la Communauté FrançAise de Belgique (1998). Decree dated 30 June 1998 aiming to ensure that all pupils have an equal opportunity for social emancipation, particularly by the implementation of positive discrimination (Moniteur: 22 August 1998).

Gouvernement de la Communauté FrançAise de Belgique (2001). Decree dated 14 June 2001 dealing with the integration of newly arrived pupils into education organised or subsidised by the French Community (Moniteur: 17 July 2001).

Gouvernement de la Communauté FrançAise de Belgique (2002). Decree dated 27 March 2002 modifying the decree dated 30 June 1998 aiming to ensure that all pupils have an equal opportunity for social emancipation, particularly by the implementation of positive discrimination and including various modified measures (Moniteur: 16 April 2002).

Gouvernement de la Communauté FrançAise de Belgique (2004a). Decree dated 28 April 2004 pertaining to the differentiation in funding of fundamental and secondary schools (Moniteur: 28 June 2004).

Gouvernement de la Communauté Française de Belgique (2004b). French Community government order defining a plan for evaluating and following up positive discrimination, in application of Article 5, $\S 2$, of the decree dated 10 June 1998 aiming to ensure that all pupils have an equal opportunity for social emancipation, particularly by the implementation of positive discrimination.

Gouvernement de la Communauté Française de Belgique (2006). Decree dated 2 June 2006 pertaining to the outside evaluation of the attainments of pupils in compulsory education and to the basic school certificate at the end of primary education (Moniteur: 23 August 2006).

\section{Endnotes}

1. Author's note: We would like to thank Bernard Delvaux (UCL) for his critical reading of this text.

2. See official web site of Belgian Government: http://www.belgium.be/en/about_belgium/government/

3. As from 1989, the legislation of teaching has developed separately in the different Communities, and is implemented on the basis of decrees from the Communities which, as regards education, have the force of law. Each community has a parliament which legislates by decree, mainly for cultural matters and teaching (Beckers, 2006). The reader interested in a short presentation of the Belgian political system can consult the website of the centre for sociopolitical research and information: <http://www.crisp.be $>$ (consulted on 4 July 2008).

4. Here already there is a slight difference in interpretation between the two communities: on the 18th birthday day in Flanders; at the end of the school year during which the young person reaches 18 in the French Community.

5. Secondary education is structured into three principal courses, both in the Flemish Community and in the French Community: general education, technical education and vocational training.

6. Philosophical convictions, the initial reason for this freedom of choice, weighs today less and less heavily in families' decisions. 
7. Three educational networks coexist in Belgium: the Community network, organised and financed by the respective communities; the official subsidised network, organised by an organising authority (town or province) and subsidised by the relevant community; and the free subsidised network (denominational or not), organised by a private organising authority (diocese, religious congregation, non-profit-making association) and subsidised by the relevant community.

8. The core competencies are indicated as the "frame of reference presenting in a structured way the basic competencies to be practised until the end of thee first eight years of compulsory education and those which are to be mastered at the end of each stage of these because they are regarded as necessary for social integration and continuation of studies' (Decree 'Missions' dated 24 July 1997 in the French Community, Article 119. A similar definition is included in a Flemish decree).

9. An external certifying evaluation system at the end of primary school education was set up by decree in 2006. All schools are now required to take part since June 2009. Nevertheless it is forbidden to publish or compare results at the school level.

10. This was the term used by the government of the French community itself (Contrat pour l'École - Contract for the school, - 2005).

11. The term 'teaching' does not indicate only the act of teaching but also refers to all the parameters (work conditions, etc.) that make up the process of teaching.

12. As Carroll (1963) understands it, the means really devoted to learning are partly provided by the school (teachers, quality of teaching, quality of the teaching materials, etc.) and therefore 'changeable', and partly provided by the pupil (prerequisites, help at home, etc.), and therefore 'unchangeable' by any thing that is done to change school.

13 There is no adequate English translation of this expression encadrement différencié. It approximately means 'differentiated funding', although it has a broader meaning, including pedagogical aspects.

14. The notion of district is taken to mean a statistical division of the region: 'a statistical sector, as defined by the Institut National de Statistique, in particular for general population censuses' (Demeuse, 2002, p. 219).

15. The 11 variables currently used to calculate the socio-economic index, subject to government approval, come under the following six fields (Decree dated 27 March 2002):

- per capita income;

- level of education;

- unemployment rate, percentage of activity and percentage people receiving the guaranteed minimum monthly income;

- professional activities; and

- housing comfort.

16 According to the decree, an underprivileged district is one where (1) standards of living are low; (2) the level of unemployment is high; and (3) there is a high percentage of families receiving social welfare.

17. In the French Community of Belgium, an educational school may be made up of several distinct sites on different locations, sometimes several kilometres apart. A school is defined as a 'pre-school and/or primary or secondary teaching unit, located in one or more places, directed by the same head-teacher' whereas a site is part of a school defined as a 'building or set of buildings located at a single address ...' (Decree dated 30 June 1998, Article 3). 
18. The priority positive discrimination sites account for 45 per cent of pupils benefiting from positive discrimination.

19. Law dated 8 December 1992.

20. According to M. Demeuse (2002), many problems may occur throughout the socioeconomic status data collection process: inaccurate answers from young pupils or parents, the informant or the person in charge of encoding overestimating his profession, poor knowledge of the nomenclatures used, etc.

21 Priority 2: lead each young person to master basic competencies.

22 Priority 9: 'no' to ghetto schools.

23. For the sake of completion, it may be mentioned that there also exists a third type of targeting: assumption of responsibility for pupils suffering from handicap, but this is does not specifically relate to priority education. In the French Community, since 1971, there has existed specialised teaching, organised in structures distinct from ordinary teaching (in special schools), and providing education for both children suffering from physical handicaps or deficiency and those suffering from intellectual deficiency. Approximately 4 per cent (4.9 per cent for primary schools, and 3.9 per cent for secondary schools) of all pupils in compulsory education attended these structures during the 2004-2005 school year (Etnic, 2006a). This figure, higher than in the other European countries (less than 3 per cent according to Eurydice, 2005), suggests that the criteria of guidance towards specialised education include a larger population.

24. This percentage is determined as follows: A is the 'teachers' pay' budget; $\mathrm{B}$ is the 'school subsidies' budget; $\mathrm{C}$ is the 'positive discrimination' budget (pay + subsidies): $\mathrm{C} /(\mathrm{A}+\mathrm{B})=$ 0.0045 .

The 'pay' budgets include employer contributions but not pensions because these come under jurisdiction of the Federal state.

25. The teachers are paid directly by the French Community of Belgium, whatever the teaching network. For this purpose, the schools do not receive a sum of money enabling them to pay the teachers' wages, but a certain number of 'teacher-periods' representing the number of teachers to be engaged according to the number of pupils enrolled in the school. Charts exist for converting the number of pupils into the number of teacher-periods granted.

26. The average socio-economic index is not actually the only parameter weighting the assignment of allocations. It counts for $80 \%$ of the weighting, the remaining $20 \%$ depending on the size of the school, in order to compensate for the costs inherent in managing a small school.

27. The dimension of accountability, used in English, is far from present in the Frenchspeaking Belgian education system. A certain change does, however, seem to be taking place, with the arrival of external evaluations, some of which lead to qualifications (decrees dated 2 June 2006).

28. The 'Missions' decree established cycles for the first eight years of compulsory schooling, seen as a teaching continuum in five cycles: the start of nursery school at age 5; from five years to the end of the second year of primary school; the third and fourth years of primary school; the fifth and sixth years of primary school; and the first two years of secondary school.

29. And yet there is the case of newly arrived pupils (see below) who obtain a score of -2.7 on a scale that ranges between -3.5 and +3.5 .

30. 'Newly arrived pupils' are pupils living in the region for less than one year and who are recognised as refugees or stateless people, or who have requested such recognition; are minors accompanying a person recognised as a refugee or stateless person or who has requested such 
recognition; or are nationals of a developing country or a country of transition (Decree dated 14 June 2001, Article 2, $1^{\circ}$ )

31. Schools where a bridge class can be organised must meet the following conditions:

For the Walloon region: be located in a town where there is a candidate refuge centre, with at least eight children aged between 5 and 12 years for the primary level, or 10 children aged between 12 and 18 years for the secondary level;

For the Brussels-Capital region, a bridge class can be created in a maximum of 14 schools in the primary sector, and a maximum of 16 schools in the secondary sector.

Have filed a request to organise the bridge class, including a project for receiving, guiding and integrating newly arrived pupils.

32. Teachers in the French Community must follow six half-days of training a year, organised by the in-service training institute.

33. External backwardness refers to how far behind the pupil is lagging, cumulated over one or more other schools, before he/she enrolled in the school under consideration. Internal backwardness expresses how far behind the pupil is lagging within the school under consideration (Demeuse et al., 2006).

34 The target group was defined on the basis of two criteria:

- the pupil's grandmother on the mother's side did not have Belgian nationality at birth and was born outside Belgium;

- the pupil's mother did not attend school past age 18 .

35 Again, the methodology cannot be considered very orthodox, as non-EPP schools must differ from EPP schools on some points (e.g. the overall share of the target group in their student population).

36 The five criteria listed here apply to basic education and the first two grades of secondary education. More restrictive criteria (based on previous educational achievement) are used in the upper grades of secondary school. As a consequence, the impact of EEO is secondary education is much smaller.

37 The linguistic criterion applies only in combination with other criteria to determine the EEO-weight of a pupil. In practice, only pupils from immigrant families are being targeted.

38 EEO funding in (upper) secondary education has remained marginal. This is partly the result of a deliberate option to concentrate resources at the start of the school career.

39 This Dutch expression 'witte school', literally translated here, denotes schools comprising almost exclusively native middle- and upper-class pupils.

40 For this reason, unlike the French community, the socio-economic index based on pupils' district of residence had been rejected as a basis for the calculation of subsidies.

41 In addition to the Flemish and French communities, Belgium also comprises a small German-speaking community.

42 For this reason, the mother tongue of students is currently subordinated to other social criteria: in EEO funding, non-Dutch speaking pupils attract higher subsidies only if they also meet other criteria of social disadvantage.

43. Within the framework of educational policies, university teams are more and more involved in proposing prospective analyses and not simply evaluating existing situations. From this point of view, the very nature of researchers' work has been modified (Aubert-Lotarski et al., 2007).

44. That is how pupils who are lagging behind in other schools are dealt with when they join the school under consideration. 
